\title{
Hydrological Processes in Eucalypt and Pine Forested Headwater Catchments within Mediterranean Region
}

\author{
Anne-Karine Boulet $1,2, * \mathbb{0}$, Mitas E. Rial-Rivas ${ }^{2}$, Carla Ferreira ${ }^{1,3,4}\left(\mathbb{D}\right.$, Celeste O. A. Coelho ${ }^{2}$, \\ Zahra Kalantari ${ }^{3,4,5}$, Jan Jacob Keizer ${ }^{2}$ (D) and António J. D. Ferreira ${ }^{1}$ (1) \\ 1 CERNAS, Coimbra Agrarian Technical School, PC 3045-601 Coimbra, Portugal; cferreira@esac.pt (C.F.); \\ aferreira@esac.pt (A.J.D.F.) \\ 2 CESAM-Environment and Planning Department, Campus Universitário de Santiago, University of Aveiro, \\ PC 3810-193 Aveiro, Portugal; m.rial@ua.pt (M.E.R.-R.); coelho@ua.pt (C.O.A.C.); jjkeizer@ua.pt (J.J.K.) \\ 3 Department of Physical Geography, Stockholm University and Bolin Centre for Climate Research, \\ SE-10691 Stockholm, Sweden; zahra.kalantari@natgeo.su.se \\ 4 Navarino Environmental Observatory, 24001 Messinia, Greece \\ 5 Department of Sustainable Development, Environmental Science and Engineering (SEED), KTH Royal \\ Institute of Technology, SE-10044 Stockholm, Sweden \\ * Correspondence: anne.karine@esac.pt; Tel.: +351-968062462
}

check for

updates

Citation: Boulet, A.-K.; Rial-Rivas, M.E.; Ferreira, C.; Coelho, C.O.A.; Kalantari, Z.; Keizer, J.J.; Ferreira, A.J.D. Hydrological Processes in Eucalypt and Pine Forested Headwater Catchments within Mediterranean Region. Water 2021, 13, 1418. https://doi.org/10.3390/ w13101418

Academic Editor: David Post

Received: 28 February 2021

Accepted: 14 May 2021

Published: 19 May 2021

Publisher's Note: MDPI stays neutral with regard to jurisdictional claims in published maps and institutional affiliations.

Copyright: (c) 2021 by the authors. Licensee MDPI, Basel, Switzerland. This article is an open access article distributed under the terms and conditions of the Creative Commons Attribution (CC BY) license (https:// creativecommons.org/licenses/by/ $4.0 /)$.

\begin{abstract}
Mediterranean headwater catchments have experienced major land-use changes in recent centuries, namely characterized by afforestation with fast-growing tree species (e.g., pine and eucalyptus). This paper investigates differences in the hydrological response of two forested catchments with distinct Pinus pinaster Aiton (PIN) and Eucalyptus globulus Labill. (EUC) covers over 6 hydrological years, from 2010 to 2016. The study was developed in paired catchments located in North-Central Portugal, under wet Mediterranean climate and schist bedrock. Based on rainfall and streamflow measurements, the hydrological responses were analyzed through the water-balance calculations, rainfall-runoff event analyses, and correlations between rainfall characteristics, evapotranspiration, soil moisture, overland flow, and land-cover parameters. The study period recorded a wide range of annual rainfall, between 984 and $2127 \mathrm{~mm}$ per years. The annual streamflow displayed greater inter-annual variation, from 208 to $1430 \mathrm{~mm}$ for PIN and from 217 to $1291 \mathrm{~mm}$ for EUC. The runoff coefficient was higher in the wettest years, with a maximum of $58 \%$ for PIN and $61 \%$ for EUC, and decreased substantially in the driest year, representing only $17 \%$ of the rainfall in PIN and $22 \%$ in EUC. Rainfall was predominant during the winter season (41\%), followed by autumn (30\%) and spring (24\%). The streamflow displayed a seasonal behavior in both catchments, with higher runoff coefficient for EUC that for PIN. Half of the annual streamflow occurs during the winter, with the highest average runoff coefficient attained for EUC and PIN respectively being $68 \%$ and $64 \%$ of the rainfall amount. Annual evapotranspiration was relatively constant through the six years of study and showed higher average values in PIN $(907 \mathrm{~mm}$ ) than EUC $(739 \mathrm{~mm})$, highlighting the importance of forest type and showing that mature pine plantations lead to higher water consumption than eucalypt stands. Annual rainfall amount affects evapotranspiration rate (\%), the percentage of ET increasing from $37 \%$ to $78 \%$ for PIN and from 34\% to $73 \%$ for EUC between the wettest and the driest years, which raises concerns regarding the impact of climate changes on water availability in the mountain areas of the Mediterranean region.
\end{abstract}

Keywords: afforestation; hydrological processes; paired catchments; Pinus pinaster Aiton; Eucalyptus globulus Labill.; schist; wet Mediterranean

\section{Introduction}

Mediterranean headwater catchments have experienced major land-use changes over the last century, mostly characterized by increasing natural vegetation as a consequence of agricultural land abandonment [1-3]. This trend continued as the increasing demand for 
wood products and the growing pressures generated an increasing worldwide interest in the afforestation of unproductive lands with fast-growing tree species [4]. FAO (2001) [5] predictions indicate that plantations will cover $5 \%$ to $10 \%$ of the world's forested land area and that close to $50 \%$ of commercially harvested wood will come from these plantations. However, global climate change could lead to a drier climate in the Mediterranean basin [6], therefore threatening existing forest stands that are highly sensitive to the strong aridity gradient of the region [7]. Both large-scale afforestation and deforestation could have major impacts on the hydrological cycle [8,9]. This highlights the importance of a detailed process-based understanding of the relationship between land use-especially forests_-and the water balance in this region.

Evapotranspiration is one of the main processes responsible for changes in annual water yield after alterations in land use [10]. The influence of land-use changes on soil water movement [11] leads to changes in the amount of water available for plant respiration, growth and evapotranspiration. Catchment response to rainfall is also altered by the moisture status of soil surface [11-16]. Land use is also one of the most important factors controlling intensity and frequency of overland flow, due to differences in surface storage that change the partitioning between infiltration and surface runoff $[9,17]$. However, land use not only alters surface runoff processes but can also affect subsurface flow [13,18].

There has been extensive research on the processes behind the impacts of land-use changes on the hydrological cycle and erosion processes [19]. In the Mediterranean region, most of these studies had been developed in abandoned agricultural lands in Northeast Spain [3,13,20-22], Southern Spain [23,24], France [25,26], and Greece [26,27]. From the studies developed in Portugal, a few have addressed the implications of land abandonment $[17,26,28]$ but the majority concerned land-use changes after forest fires [24,29-36]. Overall, there is a clear lack of data for the Mediterranean regarding the changes due to afforestation of agricultural lands and reforestation with different forest types.

Portugal is an illustrative case-study for Mediterranean afforestation. It is the European country where the transition from deforestation to reforestation was quicker [37]. The forest area increased from a total of $4-7 \%$ of the Portuguese continental area in 1870 [37] to $36 \%$ in 2018 [38]. This is a results of the Portuguese afforestation plan, which supported the plantation of 420.000 hectares of tree stands from 1938 to 1977, in particular with $\mathrm{Pi}$ nus pinaster Aiton and Eucalyptus globulus Labill. [39-41]. Between 1995 and 2018, eucalypt plantations in Portugal increased considerably in comparison with pine plantations and, in 2018, were the dominant forest type occupying 844.000 hectares or $26 \%$ of the Portuguese continental forested territory [38]. The production of eucalypt in the coastal region of Central and North Portugal is double than pine [42]. Despite these major land-use changes and the widely acknowledged relevance of forests for the overall availability of water resources in Portugal, the impacts of afforestation on the hydrological cycle continue poorly quantified [37].

Comparison of paired catchments has been widely used to quantify the impacts of afforestation/deforestation on hydrological response [43-49]. This approach assumes that the principal components of the hydrological cycle can be measured with sufficient accuracy, so that the losses by evapotranspiration can be estimated for each of the catchments being compared. In the present study, two small headwater forest catchments dominated by maritime pine and eucalypt plantations are investigated, aiming to assess their hydrological responses, including streamflow and evapotranspiration. The differences observed in both catchment responses prompted an attempt to identify the hydrological mechanisms that would explain the influence of land cover on the catchment hydrological behavior.

\section{Materials and Methods}

\subsection{Study Area}

The study was developed in the Caramulo mountain, within the Vouga River Basin $\left(3600 \mathrm{~km}^{2}\right)$, in North-Central Portugal, which is a good example of afforestation in Portugal $[41,50,51]$. Two paired catchments located in the foothills of the mountain were selected 
for the study (Figure 1): the Lourizela and Serra de Cima catchments, which have been extensively planted with Pinus pinaster Aiton (PIN) and Eucalyptus globulus Labill. (EUC), respectively, over the last decades.

The climate of Caramulo mountain is temperate with wet winters and dry summers, and can be classified as Csb according to the Köppen's system. The long-term average monthly temperature ranges from $19.8^{\circ} \mathrm{C}$ in August to $5.8^{\circ} \mathrm{C}$ in January [52] and the mean annual precipitation varies between 1200 and $1400 \mathrm{~mm}$ [53].
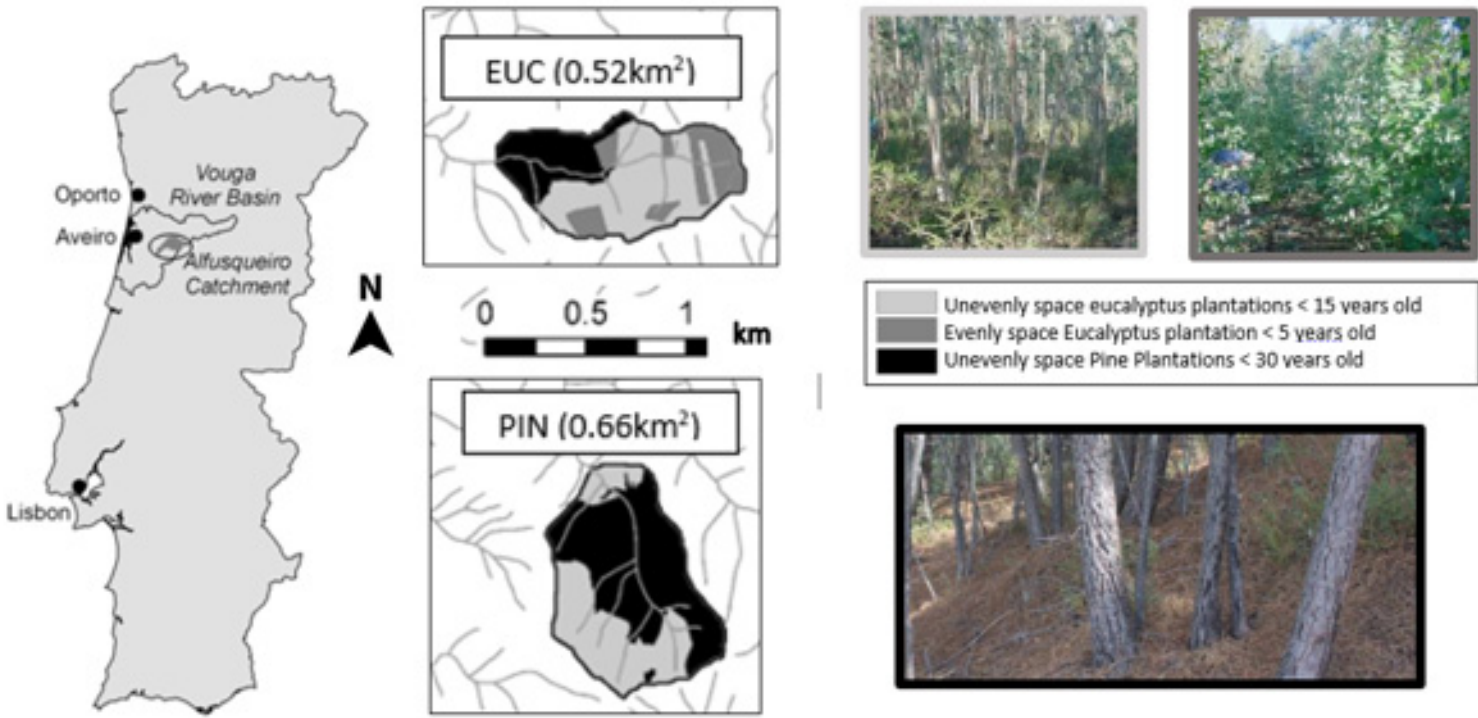

Unevenly space eucalyptus plantations $<15$ vears old Evenly space Eucalyptus plantation < 5 years old Unevenly space Pine Plantations < 30 vears old

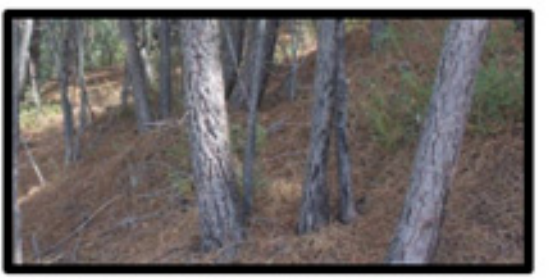

Figure 1. Location and land use of the two study catchments, Lourizela (PIN) and Serra de Cima (EUC), in North-Central Portugal.

\subsubsection{Geomorphologic Characteristics of the Study Catchments}

Table 1 presents the main topographic characteristics of the two study catchments. PIN catchment has a slightly larger area ( $\left.0.65 \mathrm{vs} .0 .52 \mathrm{~km}^{2}\right)$ and steeper slope (32\% vs. $\left.28 \%\right)$ than EUC, but lower mean elevation (255 vs. $212 \mathrm{~m}$ ).

Both catchments are crossed by a main stream of similar length, but their longitudinal profiles are different, with PIN presenting a steeper slope than EUC. The main orientation of the catchments is different, with PIN facing S-N and EUC E-W slopes.

Table 1. Main topographic characteristics of the two study catchments: Lourizela (PIN) and Serra de Cima (EUC) covered mainly by Pinus pinaster Aiton and Eucalyptus globulus Labill., respectively.

\begin{tabular}{cccccccc}
\hline & $\mathbf{P}(\mathbf{m})$ & $\left.\mathbf{A ~} \mathbf{( k m}^{\mathbf{2}}\right)$ & $\mathbf{H m a x}(\mathbf{m})$ & $\mathbf{H m i n}(\mathbf{m})$ & $\mathbf{\Delta H}(\mathbf{m})$ & $\mathbf{S}(\mathbf{\%})$ & $\mathbf{O}$ \\
\hline PIN & 4150 & 0.65 & 455 & 200 & 255 & 32 & $\mathrm{~S}-\mathrm{N}$ \\
EUC & 4020 & 0.52 & 485 & 273 & 212 & 28 & E-W \\
& Tc (min) & $\mathbf{L}(\mathbf{m})$ & $\mathbf{L F P}(\mathbf{m})$ & $\mathbf{L k}(\mathbf{m})$ & $\mathbf{S c}(\mathbf{m} / \mathbf{m})$ & DD & Or \\
PIN & 31 & 1140 & 1342 & 835 & 0.171 & 1.29 & 2 \\
EUC & 34 & 1123 & 1434 & 921 & 0.142 & 1.78 & 2 \\
\hline
\end{tabular}

P, catchment perimeter; $\mathrm{A}$, catchment area; Hmax, maximum elevation; Hmin, minimum elevation; $\Delta \mathrm{H}$ mean catchment elevation; S, mean catchment slope; $\mathrm{O}$, orientation; Tc, concentration time; L, main stream length; LFP, longest flowpath; Lk, total network length; Sc, mean channel slope; DD, drainage density; Or, stream order.

\subsubsection{Geology and Soils}

The geology of Caramulo mountain is characterized by Paleozoic metasediments of the Schist and Greywacke Complex, intruded by Hercynian granites [54]. Although schist is the unique parent material in both catchments, PIN is overlaid by shallow $(<25 \mathrm{~cm})$ Umbric Regosols, whereas EUC also includes Humic Cambisols [55]. Previous studies have performed soil sampling and analyses of some physical properties and organic matter 
content, as summarized in Table 2 [56-59]. Soil texture in both PIN and EUC is silt loam. Saturated hydraulic conductivity is high due to the presence of macro-pores in the forested soils, associated to their elevated stone content $[29,59]$. The study catchments frequently exhibit elevated soil water repellency, underneath both pine and eucalypt trees, especially during dry spells [50,58,60-63].

Soil mean depth represent the average of the depths obtained at the samples profiles realized in the study areas and represent the distance until the impervious schist bedrock interface. Soils are particularly shallow and show a gradient in term of depth from the top of the slope to the bottom. In fact, due to erosion factors the top of the slope usually presented much thinner soil that near the streambed. In term of hydrological setting, a previous study in the area highlight that Hortonian overland flow due to the strong soil water repellence is dominant during dry season, but produces residual amount. Subsurface flow is the dominant mechanism, it originates from matrix flow and pipe flow at the soil-bedrock interface, principally during the wet season. Matrix flow is correlated with soil moisture content, with a threshold of $25 \%$. Pipe flow starts with saturation of soil bottom, due to a large network of macropores, without saturation of all the soil profile. Stream flow response is highly correlated with matrix flow behavior in timing and intensity. Soil water repellency induces a very patchy 25 moistening of the soil, concentrates the fluxes and accelerates them almost 100 times greater than normal percolation of the water in the matrix [64].

Table 2. Soil types and physical characteristics in both Lourizela (PIN) and Serra de Cima (EUC) study areas.

\begin{tabular}{|c|c|c|c|c|c|c|c|c|c|c|}
\hline \multirow{2}{*}{ Catchment Name } & \multirow{2}{*}{ Soil Type } & \multirow{2}{*}{ Horizon } & \multirow{2}{*}{ Mean Depth (cm) } & \multirow{2}{*}{$B D\left(g / \mathrm{cm}^{3}\right)$} & \multirow{2}{*}{ OM (\%) } & \multicolumn{4}{|c|}{ Particle Size Distribution (\%) } & \multirow{2}{*}{ Ksat $(\mathrm{mm} / \mathrm{h})$} \\
\hline & & & & & & Coarse & Sand & Silt & Clay & \\
\hline PIN & Umbric Regosol & 1 & 25 & 0.98 & 8 & 43 & 36 & 52 & 12 & 70 \\
\hline EUC & Humic Cambisol & 1 & 30 & 0.89 & 13 & 18 & 21 & 56 & 23 & 70 \\
\hline EUC & Humic Cambisol & 2 & 65 & 1.03 & 5 & 14 & 26 & 55 & 19 & - \\
\hline EUC & Umbric Regosol & 1 & 35 & 0.98 & 13 & 50 & 23 & 59 & 18 & 70 \\
\hline
\end{tabular}

$\mathrm{D}$, bulk density; OM, organic matter.

\subsubsection{Land Use and Vegetation}

The current land use in the study catchments was characterized using aerial photography interpretation, complemented with detailed field verification. The EUC catchment was dominated by eucalypt plantations (Eucalyptus globulus Labill.), occupying 73\% of the area, and $27 \%$ was covered by pine plantations (Pinus pinaster Aiton). On the other hand, PIN catchment is mostly covered by pine plantations $(61 \%)$, with a minor area of eucalypt (39\%).

The pine plantations in the study catchments are all composed by unevenly spaced trees regrowth naturally after a wildfire in 1991, with trees about 19 years old at the beginning of the study and 25 years old at the end of the study. They presented a well-developed ground cover, mainly consisting of litter $(8-20 \mathrm{~cm}$ thick) and, to a lesser extent, shrubs. The eucalypt plantations in the catchments, however, can be divided into two different types. The most common type is unevenly spaced eucalypt plantations, in different rotation cycles, but always with trees under 15 years old (as trees are usually cut around 12 years old for paper pulp production) presented an important component of ground cover provided by shrubs and litter (5-15 cm thick). This type includes the bulk of the eucalypt plantations in PIN, as well as two thirds of the plantation in EUC. The second type is eucalypt stands planted in 2010, on terraced and flat terrain. They are only present in EUC, occupying 7\% and $15 \%$ of the total area of the catchment. This type is characterized by high percentage cover of bare soil and stones (Figure 1).

\subsection{Hydro-Meteorological Data Collection}

Hydrometric stations at the outlet of both study catchments were installed and recorded the water level at 2-min intervals, from October 2010 until September 2016. These water level measurements were carried out in a cut-throat flume [65], using an ultra- 
sonic level transmitter (Stevens 90841) in PIN and a pressure sensor (Campbell Scientific CS450) in EUC.

Rainfall, solar radiation, air temperature, relative humidity, and wind speed and direction data were provided by Pousadas meteorological station, managed by the national meteorological authorities, and located at $\sim 3 \mathrm{~km}$ from both EUC and PIN catchments. The station has an elevation of $445 \mathrm{~m}$ a.s.l., and provides data with 15-min resolution. Two cumulative rainfall gauges were installed in each catchment in order to compare the amount of precipitation with the Pousadas station. For EUC catchment, the total cumulative rainfall amounts were similar and the rainfall data of the weather station were used. For PIN catchment, as it presented systematically total rainfall amount superior to the rainfall station, a tipping-bucket gauge was installed inside the catchment (with a resolution of $0.2 \mathrm{~mm}$ ) and its rainfall data were used for the study.

Topsoil moisture content was monitored continuously at one representative site within both study catchments, in a eucalypt stand for EUC and a pine stand for PIN. The soil moisture measurements were performed with two Decagon ECH2O EC-5 sensors installed at $2.5 \mathrm{~cm}$ depth and two at $7.5 \mathrm{~cm}$, at 15-min intervals, and stored in a DECAGON Em5b data logger.

\subsection{Data Analysis}

The data analysis carried out in this study involved the (i) calculation of the annual water balance, to assess differences in streamflow, evapotranspiration, and soil and groundwater storage; (ii) analysis of streamflow hydrographs, using hydrograph separation techniques to investigate surface runoff and baseflow components; and (iii) comparison of soil water content patterns to infer the role of different vegetation cover.

\subsubsection{Annual Water-Balance Calculation}

The water balance for both catchments was estimated following the equation of [66] Chow (1964):

$$
\mathrm{R}(\mathrm{mm})=\mathrm{ET}(\mathrm{mm})+\mathrm{Q}(\mathrm{mm})+\mathrm{Gs}(\mathrm{mm})+\Delta \mathrm{S}(\mathrm{mm})
$$

where $\mathrm{R}$ is rainfall, ET is evapotranspiration, $\mathrm{Q}$ is water yield, Gs is groundwater seepage, and $\Delta \mathrm{S}$ is soil and groundwater storage.

Base on water inflows, outflows and storage within catchments, the water used by vegetation and water storage component (including evapotranspiration, groundwater seepage and soil and groundwater storage) can be estimated as the residual quantity needed to balance the equation of continuity as follows [66] (Chow, 1964):

$$
\mathrm{ET}+\mathrm{Gs}+\Delta \mathrm{S}=\mathrm{R}-\mathrm{Q}
$$

Since the study period comprises six hydrological years, and each summer, the streamflow was zero or extremely low, it was assumed that soil moisture is the same at the beginning and end of the study period, and that soil water storage and groundwater storage variation $(\Delta S)$ can be considered as zero [29]. The value of groundwater seepage (Gs) was estimated as 5\% of annual precipitation [67].

\subsubsection{Hydrograph and Streamflow Analysis}

The rainfall events recorded during the study period were separated using a minimum

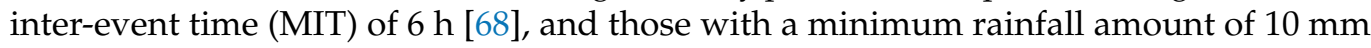
were selected for analysis.

For each event the following rainfall characteristics were calculated: total amount (Ptot, $\mathrm{mm})$, maximum intensity during $30 \mathrm{~min}(\mathrm{I} 30, \mathrm{~mm} / \mathrm{h})$, average intensity of the event $(\mathrm{Ie}, \mathrm{mm} / \mathrm{h})$ and event duration $(\mathrm{Pd}, \mathrm{hr})$. For each rainfall event the streamflow response (2-min hydrographs) was separated into the two major components, surface runoff (SR) and baseflow (BF), using an automated recursive digital filter [69], and the start and end of SR was used to separate the individual runoff events. The main characteristics of all 
streamflow events analyzed were total streamflow $(\mathrm{Q}, \mathrm{mm})$, surface runoff $(\mathrm{SR}, \mathrm{mm})$, baseflow (BF, mm), and runoff coefficient (RC, \%).

The relationships between all rainfall and streamflow response variables were assessed using Spearman correlation coefficient, performed in excel software.

\section{Results}

\subsection{Characterization of the Rainfall Pattern over the Study Period}

Annual rainfall was highly variable over the six hydrological years investigated, which included one dry year $(984 \mathrm{~mm})$, two regular $(1259$ and $1372 \mathrm{~mm}$ ) and three wet years (from 1839 to $2127 \mathrm{~mm}$ ). This rainfall was recorded at Pousadas station, and was slightly lower than that measured by the rain gauge installed in PIN. Based on both rainfall data sources, total rainfall in PIN and EUC are linked by the following equation:

$$
\mathrm{PIN}=1.185 \text { EUC }-0.256\left(\text { with } \mathrm{R}^{2}=0.979\right)
$$

In general, during the study period rainfall was predominant in winter and autumn (representing $41 \%$ and $30 \%$ of annual rainfall amount, respectively) and was very limited during the summer (5\%). The average total rainfall duration was $940 \mathrm{~h}$ per year, although the large discrepancy between minimum and maximum annual duration (670-1452 h). The rainfall events were separated using a minimum inter-event time of $6 \mathrm{~h}$, and the 216 events recorded with a minimum rainfall of $10 \mathrm{~mm}$ were further analyzed (Table 3). The number of events analyzed per year ranged from 31 in the driest to 44 in the wettest year, averaging 34 events per year over the study period. For the investigated events ( $\geq 10 \mathrm{~mm}$ ), the daily rainfall averaged $32 \mathrm{~mm}$, although ranging from 28 to $38 \mathrm{~mm}$ over the years. The average rainfall event duration was 1.2 days (ranging between 0.9 and 1.4 days), with an average $130 \mathrm{max}$ of $10 \mathrm{~mm} / \mathrm{h}$ (associated with minimum and maximum intensities of 7.9 and $13.3 \mathrm{~mm} / \mathrm{h}$ ).

From the selected events, those greater than $30 \mathrm{~mm}$ represent $72 \%$ of the events analyzed and $31 \%$ of the total number of rainfall events recorded over the study period. Major events with rainfall greater than $60 \mathrm{~mm}$ were in limited number $(14 \%$ of all the events), but represented $43 \%$ of the total annual rainfall. Only the 3 wettest years recorded events with rainfall greater than $120 \mathrm{~mm}$.

Table 3. Characterization of rainfall events per event type.

\begin{tabular}{|c|c|c|c|c|c|c|c|c|c|c|c|c|c|}
\hline & & $\begin{array}{c}\text { Total } \\
\text { Rainfall }\end{array}$ & $\begin{array}{l}\text { Rainfall } \\
\text { Duration }\end{array}$ & $\begin{array}{l}\text { Average } \\
\text { Rainfall } \\
\text { Intensity }\end{array}$ & $\begin{array}{c}\text { Average } \\
\text { Event } \\
\text { Duration }\end{array}$ & $\begin{array}{l}\text { Average } \\
\text { I30max }\end{array}$ & & & $\begin{array}{c}\text { Total } \\
\text { Rainfall }\end{array}$ & $\begin{array}{l}\text { Rainfall } \\
\text { Duration }\end{array}$ & $\begin{array}{l}\text { Average } \\
\text { Rainfall } \\
\text { Intensity }\end{array}$ & $\begin{array}{c}\text { Average } \\
\text { Event } \\
\text { Duration }\end{array}$ & $\begin{array}{l}\text { Average } \\
\text { I30max }\end{array}$ \\
\hline $2010 / 2011$ & $\mathrm{n}$ & $\mathrm{mm}$ & days & $\mathrm{mm} /$ day & day/event & $\mathrm{mm} / \mathrm{h}$ & $2013 / 2014$ & $\mathrm{n}$ & $\mathrm{mm}$ & days & $\mathrm{mm} /$ day & day/event & Av I30max \\
\hline Total $>10 \mathrm{~mm}$ & 31 & 1026 & 35.8 & 28.7 & 1.2 & 9.9 & Total $>10 \mathrm{~mm}$ & 42 & 1821 & 60.5 & 30.1 & 1.4 & 10.2 \\
\hline$>120 \mathrm{~mm}$ & 0 & 0 & 0.0 & 0.0 & 0.0 & 0.0 & $>120 \mathrm{~mm}$ & 4 & 562 & 17.0 & 33.0 & 4.3 & 15.2 \\
\hline $120-60 \mathrm{~mm}$ & 4 & 343 & 10.4 & 33.0 & 2.6 & 17.8 & $120-60 \mathrm{~mm}$ & 7 & 478 & 16.4 & 29.1 & 2.3 & 9.6 \\
\hline $60-30 \mathrm{~mm}$ & 8 & 332 & 12.2 & 27.1 & 1.5 & 11.2 & $60-30 \mathrm{~mm}$ & 9 & 398 & 12.8 & 31.2 & 1.4 & 11.6 \\
\hline $30-10 \mathrm{~mm}$ & 19 & 351 & 13.2 & 26.7 & 0.7 & 7.6 & $30-10 \mathrm{~mm}$ & 22 & 383 & 14.3 & 26.9 & 0.6 & 8.9 \\
\hline $2011 / 2012$ & & & & & & & 2014/2015 & & & & & & \\
\hline Total $>10 \mathrm{~mm}$ & 31 & 790 & 27.9 & 28.3 & 0.9 & 8.7 & Total $>10 \mathrm{~mm}$ & 33 & 1261 & 40.4 & 31.2 & 1.2 & 13.3 \\
\hline$>120 \mathrm{~mm}$ & 0 & 0 & 0.0 & 0.0 & 0.0 & 0.0 & $>120 \mathrm{~mm}$ & 0 & 0 & 0.0 & 0.0 & 0.0 & 0.0 \\
\hline $120-60 \mathrm{~mm}$ & 0 & 0 & 0.0 & 0.0 & 0.0 & 0.0 & $120-60 \mathrm{~mm}$ & 6 & 551 & 13.9 & 39.5 & 2.3 & 19.6 \\
\hline $60-30 \mathrm{~mm}$ & 9 & 369 & 10.7 & 34.4 & 1.2 & 11.4 & $60-30 \mathrm{~mm}$ & 10 & 394 & 15.7 & 25.1 & 1.6 & 13.3 \\
\hline $\begin{array}{c}30-10 \mathrm{~mm} \\
2012 / 2013\end{array}$ & 22 & 421 & 17.2 & 24.5 & 0.8 & 7.6 & $\begin{array}{l}30-10 \mathrm{~mm} \\
2015 / 2016\end{array}$ & 17 & 317 & 10.8 & 29.4 & 0.6 & 11.1 \\
\hline Total $>10 \mathrm{~mm}$ & 35 & 1278 & 37.9 & 33.7 & 1.1 & 7.9 & Total $>10 \mathrm{~mm}$ & 44 & 2102 & 55.3 & 38.0 & 1.3 & 12.0 \\
\hline$>120 \mathrm{~mm}$ & 2 & 347 & 6.4 & 54.1 & 3.2 & 13.4 & $>120 \mathrm{~mm}$ & 4 & 946 & 17.0 & 55.8 & 4.2 & 19.3 \\
\hline $120-60 \mathrm{~mm}$ & 1 & 90 & 2.1 & 42.8 & 2.1 & 12.0 & $120-60 \mathrm{~mm}$ & 3 & 223 & 4.8 & 46.4 & 1.6 & 19.0 \\
\hline $60-30 \mathrm{~mm}$ & 10 & 420 & 12.3 & 34.3 & 1.2 & 10.7 & $60-30 \mathrm{~mm}$ & 13 & 517 & 15.5 & 33.3 & 1.2 & 15.1 \\
\hline $30-10 \mathrm{~mm}$ & 22 & 421 & 17.2 & 24.5 & 0.8 & 8.7 & $30-10 \mathrm{~mm}$ & 24 & 416 & 18.0 & 23.1 & 0.8 & 8.2 \\
\hline
\end{tabular}

The number of rainfall events per year was positively correlated with annual rainfall presenting spearman coefficient of $0.92, p<0.05$. Annual rainfall showed a lower but still significant spearman correlation with increasing duration of the events $(0.75, p<0.05)$ and rainfall intensity $(0.70, p<0.05)$. No significant correlation was found between annual rainfall and average $130 \mathrm{max}(0.14, p>0.05)$. Strong correlation was also found between total annual rainfall and the percentage of annual rainfall falling during large events ( 0.81 for events $>30 \mathrm{~mm}$, and 0.84 for those $>60 \mathrm{~mm} ; p<0.05$ ). 


\subsection{Annual Water Balance}

\subsubsection{Inter Annual Variation}

The study period covers a wide range of annual rainfall amount, varying by a factor of 2 between the driest and wettest years, from 984 to $2127 \mathrm{~mm}$ for EUC and from 1192 to $2504 \mathrm{~mm}$ for PIN, with annual average over the six years of 1617 and $1881 \mathrm{~mm}$, respectively. The year 2011/2012 can be categorize as a dry, the years 2010/2011 and 2014/2015 as medium, and the 3 others years as wet (Table 4 ).

The annual streamflow $(\mathrm{Q})$ exhibits also a larger inter-annual variation, represented by a factor of 6.8 for PIN (208 $\mathrm{mm}$ in 2011/2012 to $1430 \mathrm{~mm}$ in 2015/2016) and 6.0 for EUC ( 217 to $1291 \mathrm{~mm}$, recorded in the same years). The runoff coefficient was higher for wetter years with a maximum of $58 \%$ for PIN and $61 \%$ for EUC, and decreased substantially in the driest year, representing only $17 \%$ of the rainfall in PIN and $22 \%$ in EUC (Figure 2).

The annual streamflow increased linearly with the annual rainfall, as denoted by $R^{2}$ of 0.94 for PIN and 0.96 for EUC between both variables (Figure 3). The runoff coefficient, however, did not display a significant correlation with rainfall amount $(p>0.05)$, but increased rapidly from $20 \%$ during the driest years ( $1000 \mathrm{~mm}$ of rainfall) to $\sim 50 \%$ in medium years (1000 to $2000 \mathrm{~mm}$ of rainfall) and $\sim 60 \%$ in the wettest years (>2000 $\mathrm{mm}$ of rainfall) (Figure 3). This implies that evapotranspiration by the two species is independent of the amount of rainfall (the $\mathrm{R}^{2}$ values are very low and the linear regressions almost horizontal, with the Pinus pinaster Catchment presenting a somewhat higher evapotranspiration when compared with the Eucalyptus globulus catchment). Since the evapotranspiration amounts show little variation, when accounting it as a percentage of rainfall, there is a strong inverse relation (i.e., evapotranspiration represents a lower percentage of higher amounts of rainfall).

Annual ET did not show a linear relationship with annual rainfall, as evidenced by the low $\mathrm{R}^{2}$ of 0.26 for PIN and 0.01 for EUC (Figure 3). In fact, annual ET is relatively constant through the six hydrological years, with values ranging from $670 \mathrm{~mm}$ to $1082 \mathrm{~mm}$ in PIN and from 579 to $840 \mathrm{~mm}$ in EUC (Table 5). The lowest ETs were recorded in 2014/2015, although it was a typical year, with annual rainfall of $1372 \mathrm{~mm}$ for EUC and $1554 \mathrm{~mm}$ for PIN, but with $55 \%$ of the annual rainfall being recorded in autumn. These relatively constant annual ET values reveal almost constant water consumptions in both forest stands, indicating no real water stress even during the driest year. Annual average ET over the study period was higher in the pine forest $(900 \mathrm{~mm})$ than in the eucalypt forest $(670 \mathrm{~mm})$.

In terms of streamflow $(\mathrm{Q})$, the base flow $(\mathrm{BT})$ represents $53-65 \%$ of the annual streamflow recorded in PIN and 48-57\% in EUC. Both annual BT and surface runoff (SR) showed strong correlation with annual rainfall in both PIN (0.94 and 0.98 , respectively) and EUC $(0.98$ and $0.96, p<0.01)$. Nevertheless, no significant correlation was observed between annual rainfall and BT/SR ratio in both catchments, as this ratio remains almost constant through the six years (Table 5)

Table 4. Water-balance components in both pine (PIN) and eucalyptus (EUC) catchments, and the correlation coefficient between the different components and rainfall.

\begin{tabular}{|c|c|c|c|c|c|c|c|c|c|c|c|c|}
\hline Year & PIN R & PIN Q & PIN BT & PIN SR & PIN ET & PIN Gs & EUC R & EUC Q & EUC BT & EUC SR & EUC ET & EUC Gs \\
\hline & $\mathbf{m m}$ & $\mathrm{mm}$ & $\mathbf{m m}$ & $\mathrm{mm}$ & $\mathbf{m m}$ & $\mathbf{m m}$ & $\mathrm{mm}$ & $\mathbf{m m}$ & $\mathbf{m m}$ & $\mathbf{m m}$ & $\mathbf{m m}$ & $\mathbf{m m}$ \\
\hline $2010 / 2011$ & 1520 & 361 & 190 & 172 & 1082 & 76 & 1259 & 463 & 262 & 200 & 734 & 63 \\
\hline $2011 / 2012$ & 1192 & 208 & 119 & 90 & 924 & 60 & 984 & 217 & 104 & 113 & 718 & 49 \\
\hline $2012 / 2013$ & 2049 & 1045 & 655 & 390 & 901 & 102 & 1839 & 909 & 475 & 433 & 838 & 92 \\
\hline $2013 / 2014$ & 2465 & 1428 & 901 & 527 & 914 & 123 & 2121 & 1175 & 641 & 533 & 840 & 106 \\
\hline $2014 / 2015$ & 1554 & 807 & 528 & 279 & 670 & 78 & 1372 & 731 & 394 & 330 & 579 & 69 \\
\hline $2015 / 2016$ & 2504 & 1430 & 795 & 635 & 949 & 125 & 2127 & 1291 & 618 & 680 & 723 & 106 \\
\hline Correlation/R & & 0.97 & 0.94 & 0.98 & 0.09 & 1.00 & & 0.98 & 0.98 & 0.96 & 0.52 & 1.00 \\
\hline
\end{tabular}

R, rainfall; Q, streamflow; BT, base flow; SR, surface runoff; ET, evapotranspiration; Gs, groundwater seepage. 

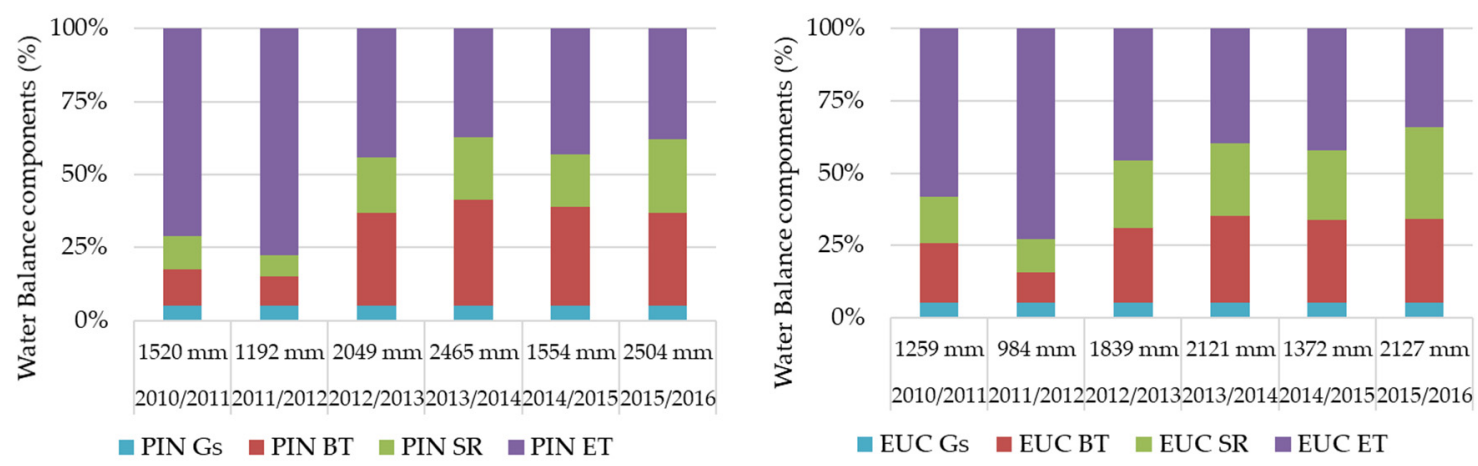

Figure 2. Components of the water balance in both Lourizela (PIN, left side) and Serra de Cima (EUC, right side) catchments, as a fraction of the total annual rainfall. Gs, groundwater seepage; BT, base flow; SR, surface runoff; ET, evapotranspiration.
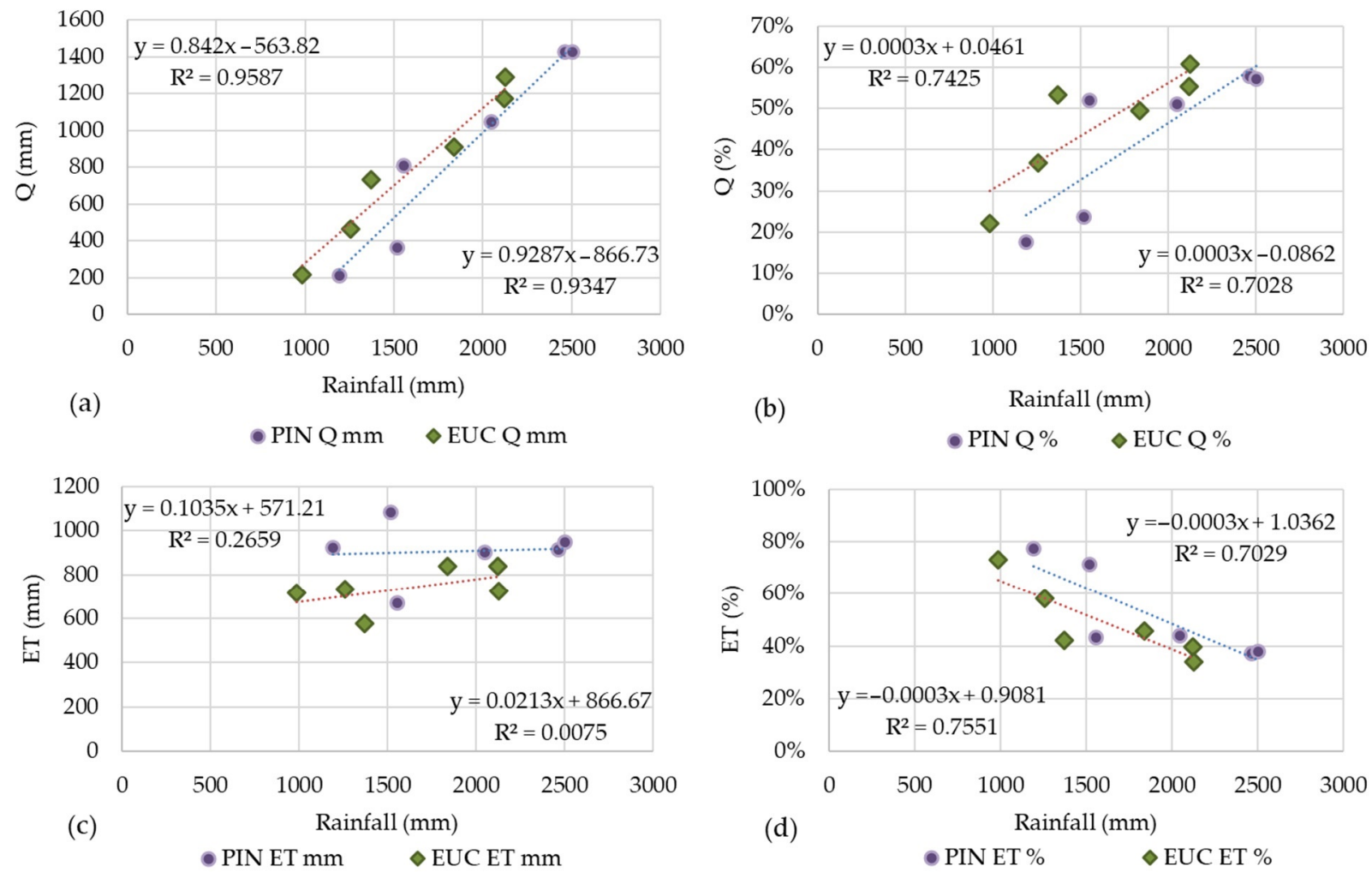

Figure 3. Linear relationship and equation in both Lourizela (PIN; right side) and Serra de Cima (EUC; left side) catchments over the 6 hydrological years investigated, recorded between annual rainfall and (a) annual streamflow (mm); (b) annual runoff coefficient (\%); (c) annual evapotranspiration (mm); (d) annual evapotranspiration coefficient (\%).

\subsubsection{Seasonal Variation}

Streamflow displayed seasonal differences over the study period (Qs). On average, streamflow during autumn represented a reduced fraction of the annual streamflow (Qt) (16\% in PIN and $14 \%$ in EUC), corresponding to seasonal runoff coefficients (Qs/Rs) of $25 \%$ for PIN and $22 \%$ for EUC, driven by a rainfall corresponding to $30 \%$ of the annual amount (Table 5). In winter, the wettest season, receiving on average $41 \%$ of the annual rainfall, streamflow accounted for the largest annual fraction, attaining $56 \%$ of the annual Q in PIN and $55 \%$ in EUC, corresponding to runoff coefficient of $64 \%$ for PIN and $68 \%$ for EUC. During spring, both seasonal rainfall (Rs) and seasonal streamflow (Qs) corresponded to $25 \%$ of the annual amount (Rt and Qt), with runoff coefficients of $50 \%$ in both catchments. 
The summer season exhibited extremely low rainfall, representing only $5 \%$ of the annual values, and thus provided only $2-3 \%$ of the annual streamflow in both catchments.

When considering the individual dry, medium, and wet years, the streamflow partition per season differs (Table 5). It is not possible to assess trends over the dry years, since the study period only included one dry year (2011/2012), but it exhibited noticeable decreases in rainfall during the autumn and particularly the winter seasons, and very low streamflow during the autumn (6\% in PIN and $8 \%$ in EUC). A significant positive correlation between rainfall and streamflow coefficient (Qs/Rs) was noticed during the autumn seasons recorded over the study period ( 0.86 for PIN and 0.92 for EUC, $p<0.05$ ). During the winter (dry) and spring (regular) seasons of this dry year, seasonal runoff coefficients were $29 \%$ and $26 \%$ for PIN and $35 \%$ and $32 \%$ for EUC, respectively, indicating almost twice lower values than those recorded during regular or wet years.

The two medium rainfall years (2010/2011 and 2014/2015) recorded higher average rainfall during the autumn than winter corresponding to $45 \%$ and $33 \%$ of the annual rainfall. Average annual streamflow during the autumn was 36\% in PIN and 33\% in EUC, corresponding to runoff coefficients of $30 \%$ for PIN and 33\% for EUC. These values are very high for the autumn season comparing with those recorded in the dry and wet years (Table 5). The winter season, despite showing lower rainfall than the autumn presented a percentage of the annual Qt of 50\% in PIN and $47 \%$ in EUC, higher than in autumn, due to a large increase of the runoff coefficient which attained $56 \%$ in PIN and $65 \%$ in EUC. The spring season of the medium rainfall years was quite dry (only $16 \%$ of the annual rainfall), leading to streamflow fractions of $12 \%$ for PIN and $17 \%$ for EUC of the annual values, and runoff coefficients of $29 \%$ in PIN and $48 \%$ in EUC. During the summer, the very low rainfall amount, corresponding to $6 \%$ of the annual values, led to Qs representing $2 \%$ of the annual Q in PIN and $4 \%$ in EUC, corresponding to runoff coefficients of $15 \%$ and $29 \%$, respectively.

The wet years $(2012 / 2013,2013 / 2014$, and 2015/2016) showed a general increase of rainfall during the winter season (average of $1127 \mathrm{~mm}$ for PIN and $954 \mathrm{~mm}$ for EUC, corresponding to $48 \%$ and $47 \%$ of the annual rainfall amount, respectively), which led to $59 \%$ for PIN and $60 \%$ for EUC of the annual streamflow, and high runoff coefficients attaining $68 \%$ for PIN and $71 \%$ for EUC. Spring recorded relatively high rainfall ( $25 \%$ of the annual rainfall) which led to the maintenance of runoff coefficients higher than $60 \%$ in both catchments. The summer season presented a typical rainfall amount $(\sim 90 \mathrm{~mm}$, corresponding to $4 \%$ of the annual rainfall amount), but with relatively high runoff coefficients of $35 \%$ for PIN and $29 \%$ for EUC.

The amount of rainfall during winter seems the main factor related with the total amount of annual rainfall, e.g., the annual variation of rainfall occurs mainly during the winter. The seasonal ratios between discharge and seasonal rainfall and between seasonal and annual discharge is an indicator of the type of forest activity. The two species are somewhat dormant during the winter, and more active during autumn and spring. For most years, the amount of streamflow during autumn is initially higher for the eucalyptus, but to the end of the period, in particular for years with very high amount of rainfall shows a stronger evapotranspiration when compared with the pine. During the winter, the amount of discharge is higher for the eucalyptus, which witnesses a lower vegetative activity. The same happens during the spring periods, where streamflow is similar or higher for eucalyptus when compared with pine (Table $5 a$ ).

The amount of streamflow, is lower for the pine for all seasons with the exception of autumn, which implies a lower evapotranspiration and therefore a lower vegetation activity (Table 5b). 
Table 5. (a) Seasonal changes in streamflow regime over the study period in the pine (PIN) and eucalypt (EUC) catchments. (b) Average seasonal changes in streamflow regime over the six hydrological years.

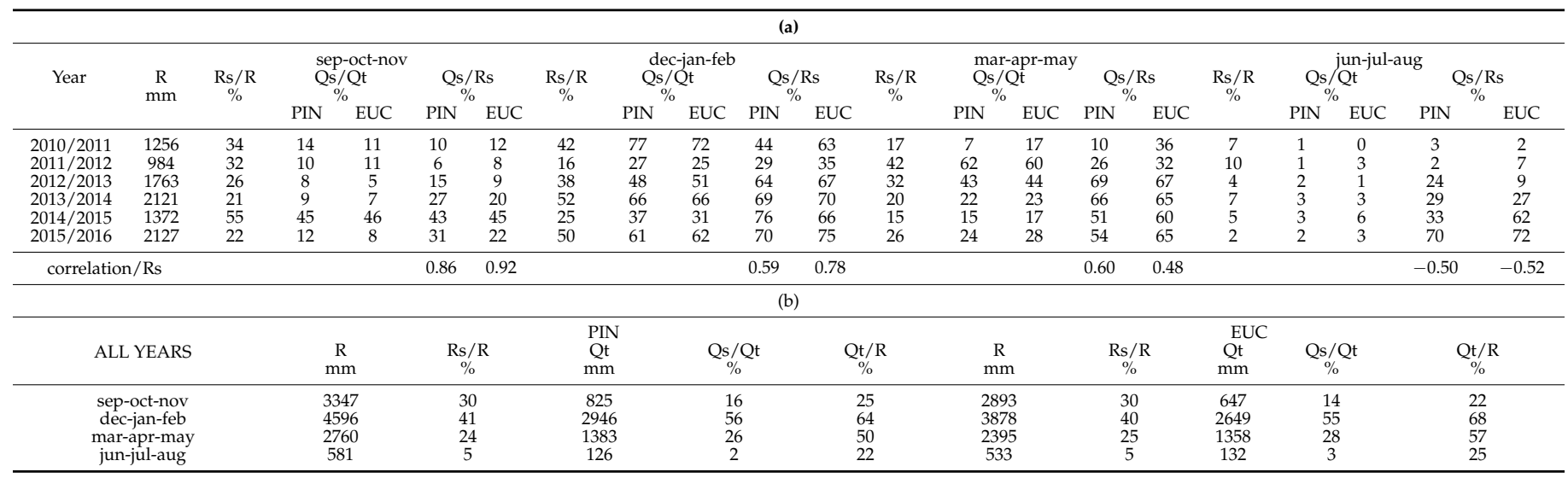

$\mathrm{R}$, annual rainfall; Rs, seasonal rainfall; Qt, annual streamflow; Qs, seasonal streamflow.

\subsection{Changes in Soil Moisture Content}

Surface (at 2.5 and $7.5 \mathrm{~cm}$ depth) soil moisture (SM) content was mostly higher for PIN than EUC catchments, as shown in Figure 4 with the example of 2012/2013 for medium hydrological year and 2013/2014 for wet year. The average SM during the study period was $20.0 \%$ in PIN and $16.5 \%$ in EUC. Considering the average daily soil moisture content, the difference between the minimum and maximum values was greater for PIN ( $3.0 \%$ vs. $52.0 \%)$ than EUC (1.7\% vs. $39.4 \%)$. Average monthly SM was also higher in PIN (4.7\% vs. $34.4 \%)$ than EUC (3.2\% vs. $32.3 \%)$.

The seasonal pattern of SM differed between years as a function of the rainfall variation, but typically attained the lowest values in the summer months (July, August, and September). The higher values did not follow such a clear pattern, but in general SM was highest in January and February, followed by November, December, and March (Figure 4).

Daily soil moisture content was positively correlated with daily rainfall and more significantly with the rainfall recorded in the 3 antecedent days (R 3 days), showing similar Spearman coefficients in both catchments $(\sim 0.55, p<0.05)$. The relation between SM and the rainfall in 3 antecedent days displays a polynomial curve, with slightly higher $\mathrm{R}^{2}$ for PIN than for EUC (0.51 vs. 0.43, Figure 5).

Daily SM recorded a positive Spearman correlation with streamflow coefficient $Q$ for both catchments $(0.57, p<0.05)$. The correlations increased when considering average monthly values, leading to Spearman correlation coefficients of 0.72 for PIN and 0.68 for SC $(p<0.05)$. Monthly baseflow presented an even stronger correlation with monthly SM, with correlation coefficients of 0.75 for PIN and 0.72 for EUC $(p<0.05)$ (Table 6).

A stronger correlation was observed between monthly soil moisture SM and streamflow coefficient Q (\%), with Spearman correlation coefficients of 0.81 for PIN and 0.71 for EUC, indicating that SM had a higher influence on runoff coefficient than streamflow amount. The higher SM content in PIN than EUC, as well as the higher amplitude of SM variation during the years, can explain the stronger correlation between SM and streamflow in PIN than EUC catchment (Table 6). 

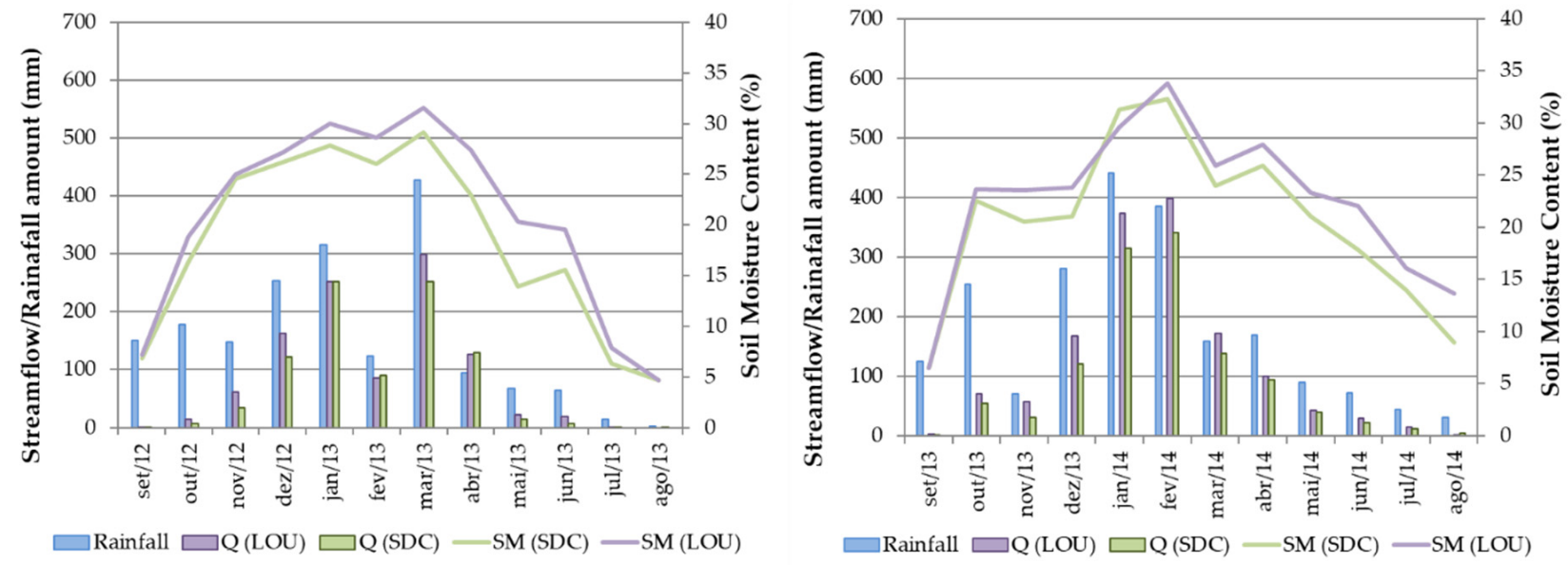

Figure 4. Average monthly rainfall, streamflow (Q) and soil moisture content (SM) for the hydrological years 2012/2013 (medium year; left side) and 2013/2014 (dry year; right side).
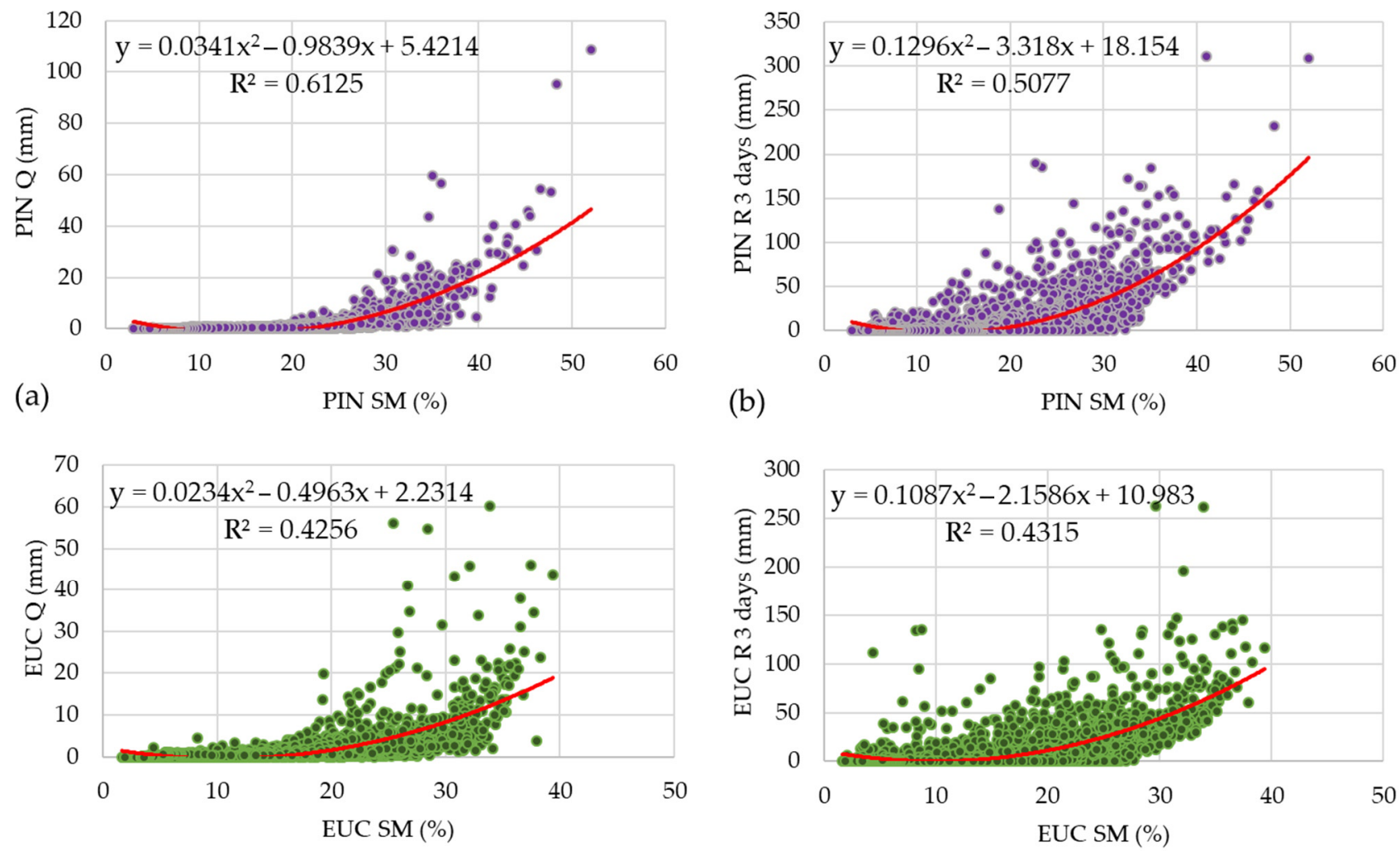

Figure 5. Polynomial relation and equation curve for PIN (top) and EUC (bottom) over the six hydrological years for average daily soil moisture content and (a) streamflow; and (b) rainfall over the 3 antecedent days. SM, soil moisture content; $\mathrm{Q}$, streamflow; R-3days, precipitation in previous 3 days. 
Table 6. Spearman correlation coefficient for average daily soil moisture content (SM) and streamflow (Q); daily antecedent rainfall (R) and rainfall in the 3 antecedent days (R-3days). Pearson correlation for monthly dataset between average soil moisture content and rainfall $(\mathrm{mm})$, streamflow ( $\mathrm{mm}$ and $\%)$, base flow (BT), and surface runoff (SR).

\begin{tabular}{cccccc}
\hline & \multicolumn{2}{c}{ Monthly Data Set } & & \multicolumn{2}{c}{ Daily Data Set } \\
& PIN & EUC & & PIN & EUC \\
\hline $\mathrm{R}(\mathrm{mm}) / \mathrm{SM}(\%)$ & 0.67 & 0.66 & $\mathrm{R}(\mathrm{mm}) / \mathrm{SM}(\%)$ & 0.43 & 0.41 \\
$\mathrm{BT}(\mathrm{mm}) / \mathrm{SM}(\%)$ & 0.75 & 0.72 & R-3days $(\mathrm{mm}) / \mathrm{SM}(\%)$ & 0.56 & 0.55 \\
$\mathrm{SR}(\mathrm{mm}) / \mathrm{SM}(\%)$ & 0.62 & 0.59 & & & \\
$\mathrm{Q}(\%) / \mathrm{SM}(\%)$ & 0.81 & 0.71 & & & \\
$\mathrm{Q}(\mathrm{mm}) / \mathrm{SM}(\%)$ & 0.72 & 0.68 & $\mathrm{Q}(\mathrm{mm}) / \mathrm{SM}(\%)$ & 0.53 & 0.53 \\
\hline
\end{tabular}

\section{Discussion}

Afforestation has major impacts on the evapotranspiration and the total amount of annual water yield [70]. This is a major issue where a significant decrease in streamflow and aquifer recharge may endanger the access to water. This is particularly true in a climatic change context, where the increase of afforested area may jeopardize other downstream activities and unbalance the functioning of ecosystems, leading to disruption of processes, and loss of environmental services provided by healthy ecosystems. This is the case of Central Portugal, a region in the transition from an Atlantic to a Mediterranean type of climates, where two imported species, managed as widespread commercial crop stands have an important role in the evapotranspiration of large amounts of the available rainfall. Pinus pinaster Aiton, originally from Southwest France, was introduced in North and Central of Portugal by the Romans, and had their area widely expanded during the first half of the 20th century. The second specie, Eucalyptus globulus Labill. Was introduced from Australia more than one century ago, but expanded rapidly after the 1970s.

The impact of afforestation with Eucalyptus globulus Labill. rouse major concerns and discussions on its impacts on water resources, being in the forefront of public concern $[29,71]$.

The results show the higher average annual evapotranspiration rates in the pine forest catchment $(900 \mathrm{~mm})$ than the eucalypt forest catchment $(740 \mathrm{~mm})$. Annual ET was relatively constant during the six hydrological years indicating that even during the driest year ( $30 \%$ less rainfall than an average year), both forest stands did not suffer water stress, since no significant breakdown on eucalypt biomass production was noticed during the field work, as also reported in previous studies [58]. Eucalyptus plants are used worldwide, in particular at tropical and sub-tropical locations as cash forests plantations for fiber and wood products. In some cases [72], forest evapotranspiration is well below the annual average rainfall. Most of the studies show, nevertheless, a pronounced decrease in annual water yield [70].

Forests have longer root systems and greater leaf areas, which rend them the potential for higher evapotranspiration rates when compared with other land uses [49,70], therefore implying a significant impact on water security [73], especially at water-limited forests [74], such as those in Portugal. We demonstrated that the amount of water used for evapotranspiration remains constant, independent of the amount of water available by rainfall every year. This has a major impact on runoff and therefore on water availability, as demonstrated by our results. Soil moisture is not significantly different in the two forest stands, with the Eucalyptus showing the impact of more efficiency in growth by the Eucalyptus during the spring and early summer for the two monitored years.

This to some extent contradicts the idea commonly accepted in society and academia, regarding the high water consumption of the eucalyptus. Our results also contrast with those from Reference [29] in the same study catchments, as that study involved young pine stands, whereas our study focused on mature pine stands. The differences between our results and those from [29]) highlight the wider span of time that pine stands take to develop and, therefore, to reach the highest evapotranspiration rates. While eucalyptus reaches full development and evapotranspiration rates about 12 years after plantation, 
cut or regrowth, the pine stands need at least 20 years to reach the maturity and use to be being cut after 30-35 years.

The higher evapotranspiration recorded in the driest years in both catchments may pose an overwhelming problem to the maintenance of ecological flows in stream and rivers and for the recharge of aquifers. This concurs with other paired catchment studies on afforestation, where observed reductions in total streamflow values ranged from $41 \%$ to $69 \%$, depending on tree ages (8 to 21 years old) and reductions in the low flows reached $100 \%$ [75-77]. During the dry season, limited water availability is an important factor across the Mediterranean region [8]. This may be increasingly concerning in the future given the potential impacts of climate change. Forested areas are particularly in danger during drought periods. A way forest ecosystems adapt to new conditions set by climate change in the Mediterranean, is through an increase frequency and severity of wildfires, that provide a catastrophic reset to new climatic conditions [78,79], leading to several solutions to mitigate ecosystem degradation [80]. Climate change can also endanger the viability of forest plantations as stated by [79] for eucalyptus plantations and [81] for native eucalyptus forests, limiting the capacity to tolerate, evolve and disperse. This vulnerability is a function of exposure and sensitivity, and may reduce the adaptive capacity sharply [79].

Reference [82] identify soil moisture as the determinant factor influencing runoff response to vegetation change during droughts. Drought may lead to a reduction on tree growth and even their death in extreme cases [79] and to a reduction of runoff at water-limited forests [74], as is the case for Pinus pinaster Aiton and Eucalyptus globulus Labill. in central Portugal.

To overcome a problem that may arise from potential climate change that may hamper tree growth and the availability of water resources, land use planning has to restrict commercial forest plantations with very high evapotranspiration rates to the areas with foreseen sufficient rainfall amounts to allow for tree growth and enough runoff and aquifer recovery [83]. Another solution is the thinning of forest stands or increasing the spacing between trees, since this has been proven to reduce evapotranspiration [79] and therefore the pressure over water resources.

This is particularly important for the Portuguese Centro Region in the transition of Atlantic to Mediterranean type of climates, as it is particularly vulnerable to climate change [84].

Reference [80] points out several strategies and solutions to reduce the vulnerability to forest fire, many of them applicable to reduce the vulnerability to drought and to a foreseeable climate change.

\section{Conclusions}

This study investigated the hydrological response of two paired catchments dominated by Pinus Pinaster Aiton (PIN) and Eucalyptus globulus Labill. (EUC), located in North-Central Portugal. Over the six hydrological years investigated, both catchments showed large rainfall inter-annual variation, with a prevalence of wet years. Rainfall was more frequent during the winter season (41\%), followed by autumn (30\%) and spring $(24 \%)$, and was very low during the summer (5\%). Annual rainfall showed, in general, a positive correlation with the number of rainfall events per year; nevertheless, increases of annual rainfall were more closely related to increases of rainfall falling during the largest events $(>60 \mathrm{~mm}$ ) than to increasing number of events. Although rainfall events $>60 \mathrm{~mm}$ represented only $14 \%$ of all the events, they supplied $43 \%$ of the annual rainfall.

Annual streamflow also showed large discrepancies between years, with an increase by a factor of 6 between the minimum and the maximum streamflow amount for EUC (217 $\mathrm{mm}$ in $2011 / 2012$ and $1291 \mathrm{~mm}$ in 2015/2016) and by a factor 6.8 for PIN (208 $\mathrm{mm}$ in $2011 / 2012$ to $1430 \mathrm{~mm}$ in 2015/2016). 
A strong positive linear correlation was found between the annual rainfall and the annual streamflow amounts, with a stronger correlation in EUC than PIN. In terms of streamflow, base flow represented $60 \%$ of the annual flows in PIN and $52 \%$ in EUC. Streamflow displayed a seasonal behavior in both catchments, with about half of the streamflow flowing during the winter rainiest period ( $56 \%$ for PIN and $55 \%$ for EUC) and representing average runoff coefficients of $64 \%$ in PIN and $68 \%$ in EUC). The streamflow during the spring represents $26 \%$ and $28 \%$ of the flows recorded in PIN and EUC, respectively, with average runoff coefficients of 50\% for PIN and 57\% for EUC. In autumn, although rainfall totalize $30 \%$ of the annual values, the seasonal streamflow only represents $16 \%$ of the annual flows, associated with runoff coefficients of $25 \%$ for PIN and $22 \%$ for EUC. Only $2-3 \%$ of the streamflow flows during the summer in both catchments.

Annual evapotranspiration amount was relatively constant over the study period, and was not significantly correlated with the annual rainfall. The average annual evapotranspiration of PIN (907 mm) was higher than for EUC (739 mm), highlighting the importance of forest type and showing that mature pine plantations lead to higher water consumption than eucalypt stands. Over the year, however, seasonal evapotranspiration rates range from $37 \%$ to $78 \%$ in PIN and from 34\% to 73\% in EUC between the wettest and the driest years, which raises concerns regarding the impact of climate changes on water availability during the driest season in the mountain areas of the Mediterranean region.

Forest cover also affects soil moisture content, with PIN exhibiting slightly higher SM content than PIN, and more noticeable daily and monthly variations than EUC. Stronger positive correlations between soil moisture content and runoff coefficients were recorded in PIN. An even stronger correlation was observed between monthly SM and Q rate (\%) indicating that SM had a higher influence on runoff coefficient than streamflow amount.

Understanding the water balance and seasonal differences in runoff processes between pine and eucalypt stands, typically found in the transition from Atlantic to Mediterranean climatic regions, are of the utmost importance to improve forest management in the mountain areas and thus improve water security, particularly under the increasing scarcity scenarios favored by climate change.

Author Contributions: Conceptualization: A.-K.B. and M.E.R.-R.; methodology: A.-K.B., M.E.R.-R., and C.F.; formal analysis, A.-K.B. and M.E.R.-R.; investigation: A.-K.B. and M.E.R.-R.; resources: A.-K.B. and M.E.R.-R.; data curation. A.-K.B. and M.E.R.-R.; writing-original draft preparation: A.-K.B. and M.E.R.-R.; writing-review and editing: A.-K.B., C.F., Z.K., A.J.D.F., C.O.A.C., and J.J.K.; supervision: A.J.D.F., C.O.A.C., and J.J.K.; project administration: A.J.D.F., C.O.A.C., and J.J.K.; funding acquisition: A.J.D.F., C.O.A.C., and J.J.K. All authors have read and agreed to the published version of the manuscript.

Funding: This research was funded by the Fundação para a Ciência e a Tecnologia (FCT/MCETS), with support of FEDER, in the framework of the "Programa Operacional Portugal 2020" (COMPETE2020) and the "Programa Operacional Competitividade e Internacionalização (POCI)", through the PhD grant SFRH/BD/91690/2012 (A.-K.B.) and the post-doctoral grants SFRH/BPD/64425/2009 (M.R.-R.) and FCT-IF/01465/2015 (J.J.K.) as well as the projects SILVAQUA (POCTI/MGS/49210/2002), HIDRIA (PTDC/CTE-GEX/71651/2006) and WAFLE (PO-CI-01-0145-FEDER-031573; PTDC/ASPSIL/31573) and CESAM (UID/AMB/50017/2019).

Institutional Review Board Statement: Not applicable.

Informed Consent Statement: Not applicable.

Data Availability Statement: Not applicable.

Acknowledgments: We thank Richard A. Shakesby for his comments on parts of the manuscript and also the Associated Laboratory, CESAM-Centro de Estudos do Ambiente e do Mar (2020-2023UIDB /50017/2020 + UIDP/50017/2020) and the Investigation Unity, CERNAS-Centro de Recursos Naturais, Ambiente e Sociedade (UIDB681-2020-2023) for providing the institutional framework.

Conflicts of Interest: The authors declare no conflict of interest. 


\section{References}

1. Beguería, S.; López-Moreno, J.I.; Lorente, A.; Seeger, M.; García-Ruiz, J.M. Assessing the Effect of Climate Oscillations and Land-use Changes on Streamflow in the Central Spanish Pyrenees. Ambio 2003, 32, 283-286. [CrossRef]

2. Debussche, M.A.X.; Lepart, J.; Dervieux, A. Mediterranean landscape changes: Evidence from old postcards. Glob. Ecol. Biogeogr. 1999, 8, 3-15. [CrossRef]

3. Lasanta-Martínez, T.; Vicente-Serrano, S.M.; Cuadrat-Prats, J.M. Mountain Mediterranean landscape evolution caused by the abandonment of traditional primary activities: A study of the Spanish Central Pyrenees. Appl. Geogr. 2005, 25, 47-65. [CrossRef]

4. Lafleur, B.; Paré, D.; Claveau, Y.; Thiffault, É.; Bélanger, N. Influence of afforestation on soil: The case of mineral weathering. Geoderma 2013, 202-203, 18-29. [CrossRef]

5. FAO. Future Production from Forest Plantations; Forest Plantations Thematic Papers; FAO Forest Resources Development ServiceForest Resources Division: Rome, Italy, 2001.

6. Giorgi, F.; Lionello, P. Climate change projections for the Mediterranean region. Glob. Planet. Chang. 2008, 63, 90-104. [CrossRef]

7. Barboni, D.; Harrison, S.P.; Bartlein, P.J.; Jalut, G.; New, M.; Prentice, I.C.; Sanchez-Goñi, M.-F.; Spessa, A.; Davis, B.; Stevenson, A.C. Relationships between plant traits and climate in the Mediterranean region: A pollen data analysis. J. Veg. Sci. 2004, 15, 635-646. [CrossRef]

8. Zhang, L.; Dawes, W.R.; Walker, G.R. Predicting the Effect of Vegetation Changes on Catchment Average Water Balance; CSIRO Land and Water- Technical Reports; Cooperative Research Centre for Catchment Hydrology: Melbourne, Australia, 1999.

9. Kalantari, Z.; Ferreira, C.S.S.; Walsh, R.P.D.; Ferreira, A.J.D.; Destouni, G. Urbanization development under climate change: Hydrological responses in a peri-urban Mediterranean catchment. Land Degrad. Dev. 2017, 28, 2207-2221. [CrossRef]

10. Zhang, L.; Dawes, W.R.; Walker, G.R. Response of mean annual evapotranspiration to vegetation changes at catchment scale. Water Resour. Res. 2001, 37, 701-708. [CrossRef]

11. Edwards, K.A.; Blackie, J.R.; Eeles, C.W.O. Final Report on The East African Catchment Research Project; Experimental Methods (ODMI R2532); Instiute of Hydrology: Wallingford, UK, 1976; Volume 1, p. 108.

12. Tromp van Meerveld, I.; McDonnell, J.J. Comment to "Spatial correlation of soil moisture in small catchments and its relationship to dominant spatial hydrological processes, Journal of Hydrology, 286: 113-134". J. Hydrol. 2005, 303, 307-312. [CrossRef]

13. Latron, J.; Gallart, F. Runoff generation processes in a small Mediterranean research catchment (Vallcebre, Eastern Pyrenees). J. Hydrol. 2008, 358, 206-220. [CrossRef]

14. James, A.L.; Roulet, N.T. Antecedent moisture conditions and catchment morphology as controls on spatial patterns of runoff generation in small forest catchments. J. Hydrol. 2009, 377, 351-366. [CrossRef]

15. Webb, A.A.; Kathuria, A. Response of streamflow to afforestation and thinning at Red Hill, Murray Darling Basin, Australia. J. Hydrol. 2010, 412-413, 133-140. [CrossRef]

16. Penna, D.; Tromp-van Meerveld, H.J.; Gobbi, A.; Borga, M.; Dalla Fontana, G. The influence of soil moisture on threshold runoff generation processes in an alpine headwater catchment. Hydrol. Earth Syst. Sci. 2011, 15, 689-702. [CrossRef]

17. Nunes, N.A.; Almeida, C.A.; Coelho, C.O.A. Impacts of landuse and cover type on runoff and soil erosion in a marginal area of Portugal. Appl. Geogr. 2011, 3, 687-699. [CrossRef]

18. Peters, N.E.; Freer, J.; Aulenbach, B.T. Hydrological Dynamics of the Panola Mountain Research Watershed, Georgia. Ground Water 2003, 41, 973-988. [CrossRef]

19. Garcia-Ruiz, J.M.; Lana-Renault, N. Hydrological and erosive consequences of farmland abandonment in Europe, with special reference to the Mediterranean region. A review. Agric. Ecosyst. Environ. 2011, 140, 317-338. [CrossRef]

20. Gallart, F.; Llorens, P. Observations on land cover changes and water resources in the headwaters of the Ebro catchment, Iberian Peninsula. Phys. Chem. Earth Parts ABC 2004, 29, 769-773. [CrossRef]

21. López-Moreno, J.I.; Beniston, M.; Garcia-Ruiz, J.M. Trends in Hight flows in the Central Spanish Pyrenees: Response to climatic factors or to land-use change? Hydrol. Sci. J. 2006, 51, 1039-1050. [CrossRef]

22. Seeger, M.; Ries, J.B. Soil degradation and soil surface process intensities on abandoned fields in Mediterranean mountain environments. Land Degrad. Dev. 2008, 19, 488-501. [CrossRef]

23. Cerda, A. Soil erosion after land abandonment in a semiarid environment of southeastern Spain. Arid. Soil Res. Rehabil. 1997, 11, 163-176. [CrossRef]

24. Cammeraat, L.H.; Imeson, A.C. The evolution and significance of soil-vegetation patterns following land abandonment and fire in Spain. Catena 1999, 37, 107-127. [CrossRef]

25. Piegay, H.; Walling, D.E.; Landon, N.; He, Q.; Liebault, F.; Petiot, R. Contemporary changes in sediment yield in an alpine mountain basin due to afforestation (the upper Drome in France). Catena 2004, 55, 183-212. [CrossRef]

26. Bakker, M.M.; Govers, G.; Doorn, A.; van Quetier, F.; Chouvardas, D.; Rounsevell, M. The response of soil erosion and sediment export to land-use change in four areas of Europe: The importance of landscape pattern. Geomorphology 2008, 98, 213-226. [CrossRef]

27. Koulouri, M.; Giourga, C. Land abandonment and slope gradient as key factors of soil erosion in Mediterranean terraced lands. Catena 2007, 69, 274-281. [CrossRef] 
28. Nunes, A.N.; Coelho, C.O.A.; Almeida, A.C.; Figueiredo, A. Soil erosion and hydrological response to land abandonment in a central inland area of Portugal. Land Degrad. Dev. 2010, 21, 260-273. [CrossRef]

29. Ferreira, A.J.D. Processos Hidrologicos e Hidroquimicos em Povoamentos de Eucalyptus globulus Labill e Pinus Pinaster Aiton. Ph.D. Thesis, University of Aveiro, Aveiro, Portugal, 1996.

30. Shakesby, R.A.; Boakes, D.; Coelho, C.O.A.; Gonçalves, A.J.B.; Walsh, R.P.D. Limiting the soil degradation impacts of wildfire in Pine and Eucalyptus forest in Portugal. Appl. Geogr. 1996, 16, 337-355. [CrossRef]

31. Thomas, A.D.; Walsh, R.P.D.; Shakesby, R.A. Post-fire forestry management and nutrient losses in eucalyptus and pine plantations, Northern Portugal. Land Degrad. Dev. 2000, 11, 257-271. [CrossRef]

32. Coelho, C.O.A.; Ferreira, A.J.D.; Boulet, A.K.; Keizer, J.J. Overland flow generation processes, erosion yields and solute loss following different intensity fires. Q. J. Eng. Geol. Hydrogeol. 2004, 37, 233-240. [CrossRef]

33. Ferreira, A.J.D.; Coelho, C.O.A.; Boulet, A.K.; Leighton-Boyce, G.; Keizer, J.J.; Ritsema, C.J. Influence of burning intensity on water repellency and hydrological processes at forest and shrub sites in Portugal. Soil Res. 2005, 43, 327-336. [CrossRef]

34. Shakesby, R.A.; Bento, C.P.M.; Ferreira, C.S.S.; Ferreira, A.J.D.; Stoof, C.R.; Urbanek, E.; Walsh, R.P.D. Impacts of prescribed fire on soil loss and soil quality: An assessment based on an experimentally-burned catchment in central Portugal. Catena 2015, 128, 278-293. [CrossRef]

35. Stoof, C.R.; Ferreira, A.J.D.; Mol, W.; Van den Berg, J.; De Kort, A.; Drooger, S.; Slingerland, E.C.; Mansholt, A.U.; Ferreira, C.S.S.; Ritsema, C.J. Soil surface changes increase runoff and erosion risk after a low-moderate severity fire. Geoderma 2015, 239-240, 58-67. [CrossRef]

36. Hosseini, M.; Keizer, J.J.; Gonzalez-Pelayo, O.; Alegre-Prats, S.; Ritsema, C.; Geissen, V. Effect of fire frequency on runoff, soil erosion, and loss of organic matter at the micro-plot scale in north-central Portugal. Geoderma 2016, 269, 126-137. [CrossRef]

37. Pereira, J.S.; Correia, A.; Borges, J.G. Floresta. In Ecossistemas e Bem-Estar Humano: Avaliação para Portugal do Millennium Ecosystem Assessment; Pereira, H.M., Domingos, T., Vicente, L., Proença, V., Eds.; Escolar Editora: Lisboa, Portugal, 2009 ; pp. $184-211$.

38. IFN6; ICNF. Inventario Florestal Nacional 6-Áreas dos Usos do Solo e das Espécies Florestais de Portugal Continental; Resultados Preliminares, 34; Instituto da Conservação da Natureza e das Florestas: Lisboa, Portugal, 2019.

39. Baptista, F.O. A Política Agrária do Estado Novo; Edicões Afrontamento: Porto, Portugal, 1993.

40. Coelho, I.S. Propriedade da Terra e Política Florestal em Portugal. Silva Lusitana 2003, 11, 185-199.

41. Jones, N.; Graaff, J.; de Rodrigo, I.; Duarte, F. Historical review of land-use changes in Portugal (before and after EU integration in 1986) and their implications for land degradation and conservation, with a focus on Centro and Alentejo regions. Appl. Geogr. 2011, 31, 1036-1048. [CrossRef]

42. Soares, P.; Tomé, M.; Pereira, J.S. A produtividade do eucaliptal. In O Eucaliptal em Portugal: Impactes Ambientais e Investigação Científica; Alves, A.M., Pereira, J.S., Silva, J.M.N., Eds.; Technical University of Lisbon: Lisboa, Portugal, 2007 ; p. 398.

43. Edwards, K.A. The water balance of the Mbeya experimental catchments. East Afr. Agric. For. J. 1979, 43, 231-247. [CrossRef]

44. Bruijnzeel, L.A. Hydrological functions of tropical forest: Not seeing the soil for the trees? Agric. Ecosyst. Environ. 2004, 104, 185-228. [CrossRef]

45. Farley, K.A.; Jobbagy, E.G.; Jackson, R.B. Effects of afforestation on water yield: A global synthesis with implications for policy. Glob. Chang. Biol. 2005, 11, 1565-1576. [CrossRef]

46. Sun, G.; Zhou, G.; Zhang, Z.; Wei, X.; McNulty, S.G.; Vose, J.M. Potential water yield reduction due to forestation across China. J. Hydrol. 2006, 328, 548-558. [CrossRef]

47. Wang, Y.; Yu, P.; Xiong, W.; Shen, Z.; Guo, M.; Shi, Z.; Du, A.; Wang, L. Water-Yield Reduction After Afforestation and Related Processes in the Semiarid Liupan Mountains, Northwest China1. J. Am. Water Resour. Assoc. 2008, 44, 1086-1097. [CrossRef]

48. Wei, X.; Sun, G.; Liu, S.; Jiang, H.; Zhou, G.; Dai, L. The Forest-Streamflow Relationship in China: A 40-Year Retrospect1. J. Am. Water Resour. Assoc. 2008, 44, 1076-1085. [CrossRef]

49. Vanclay, J.K. Managing water use from forest plantations. For. Ecol. Manag. 2009, 257, 385-389. [CrossRef]

50. Ferreira, A.J.D.; Coelho, C.O.A.; Walsh, R.P.D.; Shakesby, R.A.; Ceballos, A.; Doerr, S.H. Hydrological implications of soil water-repellency in Eucalyptus globulus forests, north-central Portugal. J. Hydrol. 2000, 231-232, 165-177. [CrossRef]

51. Shakesby, R.A.; Coelho, C.O.A.; Ferreira, A.J.D.; Walsh, R.P.D. Ground-level changes after wildfire and ploughing in eucalyptus and pine forests, Portugal: Implications for soil microtopographical development and soil longevity. Land Degrad. Dev. 2002, 13, 111-127. [CrossRef]

52. Leighton-Boyce, G.; Doerr, S.H.; Shakesby, R.A.; Walsh, R.P.D.; Ferreira, A.J.D.; Boulet, A.K.; Coelho, C.O.A. Temporal Dynamics of water repellency and soil moisture in Eucalypt plantations, Portugal. Aust. J. Soil Res. 2005, 43, 269-280. [CrossRef]

53. Agência Portuguesa do Ambiente-ARH Centro. PGRH do Vouga, Mondego, Lis—RH4—Relatório Base-P2—ClimatologiaTemperatura Média Annual; Agência Portuguesa do Ambiente-ARH Centro: Coimbra, Portugal, 2011.

54. Van der Weijden, C.H.; Pacheco, F.A.L. Hydrogeochemistry in the Vouga River basin (central Portugal): Pollution and chemical weathering. Appl. Geochem. 2006, 21, 580-613. [CrossRef]

55. WRB. World Reference Base for Soil Resources 2014-International Soil Classification System for Naming Soils and Creating Legends for Soil Maps; World Soil Resources Reports 106; Food and Agriculture Organization of the United Nations: Roma, Italy, 2015.

56. Van der Veur, J. Soil Survey of The Sites Near Lourizela and Falgorosa: Soil Descriptions and Particle Analysis; IBERLIM Interim Report; University of Aveiro: Aveiro, Portugal, 1993. 
57. Thomas, A.D. The Effects of Fire and Different Logging Practices on Nutrient Losses in Overland Flow from Eucalyptus and Pine Forests, Northern Portugal; University of Wales: Swansea, UK, 1996.

58. Boulet, A.K. Escoamento Superficial nos Eucaliptais da Serra do Caramulo. Master's Thesis, University of Aveiro, Aveiro, Portugal, 2011.

59. Gosch, L. Einfluss Unterschiedlicher Forstmanagementstrategien auf Bodenhydraulische Parameter zur Standortswassermodellierung im Águeda Einzugsgebiet Zentralportugal; Dresden University of Technology: Dresden, Germany, 2012.

60. Coelho, C.O.A.; Laouina, A.; Regaya, K.; Ferreira, A.J.D.; Carvalho, T.M.M.; Chaker, M.; Naafa, R.; Naciri, R.; Boulet, A.K.; Keizer, J.J. The impact of soil water repellency on soil hydrological and erosional processes under Eucalyptus and evergreen Quercus forests in the Western Mediterranean. Aust. J. Soil Res. 2005, 3, 309-318. [CrossRef]

61. Keizer, J.J.; Coelho, C.O.A.; Shakesby, R.A.; Domingues, C.S.P.; Malvar, M.C.; Perez, I.M.B.; Matias, M.J.S.; Ferreira, A.J.D. The role of soil water repellency in overland flow generation in pine and eucalypt forest stands in coastal Portugal. Soil Res. 2005, 43, 337-349. [CrossRef]

62. Leighton-Boyce, G.; Doerr, S.H.; Shakesby, R.A.; Walsh, R.P.D. Quantifying the impact of soil water repellency on overland flow generation and erosion: A new approach using rainfall simulation and wetting agent on in situ soil. Hydrol. Process. 2007, 21, 2337-2345.

63. Santos, J.M.; Verheijen, F.G.A.; Wahren, F.T.; Wahren, A.; Feger, K.-H.; Bernard-Jannin, L.; Rial-Rivas, M.E.; Keizer, J.J.; Nunes, J.P. Soil water repellency dynamics in pine and eucalypt plantations in Portugal-A high-resolution time series. Land Degrad. Dev. 2013, 27, 1334-1343. [CrossRef]

64. Boulet, A.-K.; Prats, S.A.; Malvar, M.C.; González-Pelayo, O.; Coelho, C.O.A.; Ferreira, A.J.D.; Keizer, J.J. Surface and subsurface flow in eucalyptus plantations in north-central Portugal. J. Hydrol. Hydromech. 2015, 63, 193-200. [CrossRef]

65. Skogerboe, G.V. Cutthroat Flumes for Water Measurement; Office of Agriculture, Bureau for Technical Assistance: Ft. Collins, CO, USA, 1974; p. 22.

66. Chow, V.T. Handbook of Applied Hydrology; McGraw-Hill Book Company: New York, NY, USA, 1964; 1495p.

67. ARHC. Parte 2-Caracterização Geral e Diagnóstico. Caracterização das Massas de Águas Subterrâneas. In Plano de Gestão das Bacias Hidrográficas dos Rios Vouga, Mondego e Lis Integradas na Região Hidrografica 4; Final Revision. Administração da Região Hidrografica do Centro I.P.; Administração da Região Hidrografica do Centro: Coimbra, Portugal, 2012.

68. Gyasi-Agyei, Y.; Melching, C.S. Modelling the dependence and internal structure of storm events for continuous rainfall simulation. J. Hydrol. 2012, 249-261. [CrossRef]

69. Nathan, R.J.; McMahon, T.A. Evaluation of automated techniques for base flow and recession analyses. Water Resour. Res. 1990, 26, 1465-1473. [CrossRef]

70. Yao, Y.; Cai, T.; Ju, C.; He, C. Effect of reforestation on annual water yield in a large watershed in northeast China. J. For. Res. 2015, 26, 697-702. [CrossRef]

71. Ren, S.; White, D.A.; Xiang, D.; Short, T.M.; Xiao, W.; Chen, J.; Deng, Z.; Yang, Z. Simple model of evapotranspiration by Eucalyptus plantations for data poor areas and tested using water balance data from a small catchment in Guangxi, China. Aust. For. 2019, 82, 66-79. [CrossRef]

72. Lane, P.N.J.; Morris, J.; Ningnan, Z.; Guangyi, Z.; Guoyi, Z.; Daping, X. Water balance of tropical eucalypt plantations in south-eastern China. Agric. For. Meteorol. 2004, 124, 253-267. [CrossRef]

73. Khan, S.; Hanjra, M.; Mu, J. Water management and crop production for food security in China: A review. Agric. Water Manag. 2009, 96, 349-360. [CrossRef]

74. Zhang, M.; Liu, N.; Harper, R.; Li, Q.; Liu, K.; Wei, X.; Ning, D.; Hou, Y.; Liu, S. A global review on hydrological responses to forest change across multiple spatial scales: Importance of scale, climate, forest type and hydrological regime. J. Hydrol. 2017, 546, 44-59. [CrossRef]

75. Fahey, B.; Jackson, R. Hydrological impacts of converting native forests and grasslands to pine plantations, South Island, New Zealand. Agric. For. Meteorol. 1997, 84, 69-82. [CrossRef]

76. Brown, A.E.; Zhang, L.; McMahon, T.A.; Western, A.W.; Vertessy, R.A. A review of paired catchment studies for determining changes in water yield resulting from alterations in vegetation. J. Hydrol. 2005, 310, 28-61. [CrossRef]

77. Lane, P.N.J.; Best, A.E.; Hickel, K.; Zhang, L. The response of flow duration curves to afforestation. J. Hydrol. 2005, 310, 253-265. [CrossRef]

78. Ferreira, A.J.D.; Coelho, C.O.A.; Ritsema, C.J.; Boulet, A.K.; Keizer, J.J. Soil and water degradation processes in burned areas: Lessons learned from a nested approach. Catena 2008, 74, 273-285. [CrossRef]

79. Booth, T.H. Eucalypt plantations and climate change. For. Ecol. Manag. 2013, 301, 28-34. [CrossRef]

80. Ferreira, A.J.D.; Prats, S.A.; Coelho, C.O.A.; Shakesby, R.A.; Páscoa, F.M.; Ferreira, C.S.S.; Keizer, J.J.; Ritsema, C. Strategies to prevent forest fires and techniques to reverse degradation processes in burned areas. Catena 2015, 128, 224-237. [CrossRef]

81. Booth, T.H.; Broadhurst, L.M.; Pinkard, E.; Prober, S.M.; Dillon, S.K.; Bush, D.; Pinyopusarerk, K.; Doran, J.C.; Ivkovich, M.; Young, A.G. Native forests and climate change: Lessons from eucalypts. For. Ecol. Manag. 2015, 347, 18-29. [CrossRef]

82. Bart, R.; Hope, A. Streamflow response to fire in large catchments of a Mediterranean-climate region using paired-catchment experiments. J. Hydrol. 2010, 388, 370-378. [CrossRef] 
83. Ferreira, A.J.D. As alterações climáticas e a floresta. In Floresta Viva: Património de Futuro; Baptista, F., Jacinto, R., Mendes, T., Eds.; Centro de Ciência Viva: Proença-a-Nova, Portugal, 2009; pp. 9-24.

84. Ferreira, A.J.D.; Silva, J.S.; Rodrigues, D.; Gomes, F.; Bingre, P.; Leitão, I.; Pinto, L.; Boulet, A.-K.; Monteiro, A.; Ferreira, C. A floresta da Região Centro num contexto de alterações climáticas: Subsídios para aumentar a adaptação e a resiliência. In Livro Verde Para o Desenvolvimento Rural da Região Centro; Ferreira, A.J.D., Ed.; CERNAS: Coimbra, Portugal, 2017 ; pp. $234-256$. 